\title{
PENGEMBANGAN DISTRIBUSI PEMASARAN IKAN KERING DI KECAMATAN SASAK
}

\author{
Mia Muchia Desda ${ }^{1 *}$, Mai Yuliza ${ }^{2}$ \\ ${ }^{1,2}$ Sekolah Tinggi Ilmu Ekonomi Pasaman, Indonesia \\ E-mail: ${ }^{1)}$ mia.muchia@gmail.com ${ }^{2)}$ mai.yuliza@gmail.com
}

\begin{abstract}
Abstrak
Penelitian ini bertujuan untuk sosialisasi pembukuan sederhana bagi pelaku UKM Ikan Asin Perikanan Kampung Padang Nagari Air Bangis. Metode yang digunakan dalam pelaksanaan kegiatan PKM ini adalah melalui dua metode yakni sosialisasi peranan pembukuan sederhana bagi perkembangan UKM serta memberikan percontohan dalam perhitungan biaya produksi pada usaha ikan kering serta contoh perhitungan biaya produksi yang dikeluarkan selama satu kali proses produksi. Berdasarkan hasil wawancara yang dilakukan dengan kepala jorong Kampung Padang Air Bangis terdapat 320 Kepala Keluarga dimana 90\% mata pencaharian utama warga mereka bergerak di bidang perikanan yang terbagi pada beberapa usaha yaitu sebagai pemilik bagan ikan, nelayan, pedagang ikan keliling, penjemur ikan kering serta pemilik usaha ikan asin. $10 \%$ sisanya adalah pekerja serabutan yaitu sebagai penggulung tali rafiah. Keterbatasan modal untuk pengembangan usaha menjadi kendala bagi mereka ketika alternatif bantuan dana harus mereka dapatkan dari lembaga permodalan atau perbankan yang membutuhkan persyaratan adminitratif. Berdasarkan hasil kegiatan pengabdian dalam bentuk Sosialisasi menunjukkan peningkatan pengetahuan dan pemahaman tentang manfaat pembukuan sederhana serta bentuk-bentuk laporan keuangan.
\end{abstract}

Kata kunci: Sosialisasi, Pembukuan Sederhana, UKM Perikanan

\begin{abstract}
This study aims to socialize simple bookkeeping for SMEs salted fish fisheries in Kampung Padang Nagari Air Bangis. The method used in implementing this Student Creativity Program (PKM) activity is through two methods, namely socializing the role of simple bookkeeping for the development of SMEs and providing an example in calculating production costs in a dried fish business as well as examples of calculating production costs incurred during one production process. Based on the results of interviews conducted with the jorong head of Padang Air Bangis Village, there are 320 families where $90 \%$ of the main livelihoods of their residents are engaged in fisheries which are divided into several businesses, namely as bagan fish (fishing gear) owners, fishermen, fish traders, fish dryer and owners of salted fish business. Meanwhile, $10 \%$ are engaged on odd jobs, namely as rope rollers. Limited capital for business development becomes an obstacle when they are required to seek alternative financing from capital institutions or banks that impose administrative requirements. It demonstrates an increase in knowledge and understanding of the benefits of simple bookkeeping and other types of financial reports as a result of service activities in the form of socialization.
\end{abstract}

Keywords: Simple Bookkeeping, Fisheries SMEs 


\section{PENDAHULUAN}

Usaha Mikro Kecil dan Menengah (UMKM) tidak dapat dianggap sepeleh terutama dalam perekonomian nasional. UMKM telah berhasil menunjukkan kekuatan ekonomi rakyat dalam menghadapi dan mengatasi berbagai masalah yang perekonomian baik di daerah maupun nasional. Begitu pentingnya peranan UMKM pada perekonomian di Indonesia, maka pemerintah mengeluarkan Undang-Undang Republik Indonesia Nomor 20 Tahun 2008 yang mengatur Tentang Usaha Mikro, Kecil, dan Menengah. Sektor UMKM telah menyerap lebih dari 90 persen tenaga kerja Indonesia. Sementara, menurut Menteri Koordinator Bidang Perekonomian Airlangga Hartarto, pekerja pada sektor UMKM sebanyak 116 juta orang. Selain itu, Data Kementerian Koperasi dan UMKM, PDB 2017 menunjukkan kontribusi UMKM sebesar 60,34 persen. Kontribusi ini masih dapat ditingkatkan. UMKM terbukti tahan banting menghadapi krisis seperti yang pernah terjadi pada 2012 dan pelambatan pertumbuhan yang terjadi pada 2015 (Purba, 2019). Sementara itu, Pemerintah Kabupaten Pasaman Barat melalui Dinas Koperasi, UMKM dan Tenaga Kerja memprediksi jumlah usaha mikro di tahun 2019 lebih dari 6.800. Dari 2.155 pelaku usaha mikro yang terdata di Pasaman Barat, baru sekitar 1.950 pelaku usaha yang masuk di Sistem Informasi Kredit Program (SIKP) (Ridwan \& Tarmizi, 2020).

Menurut Kepala Dinas Dinas Koperasi dan UMKM dan Tenaga Kerja Daerah Pasaman Barat situasi saat ini pertumbuhan UMKM diprediksi baru bisa meningkat sekitar 20 hingga 30 persen karena keterbatasan permodalan masih (Yolandha, 2020). Sebagai penggerak motor perekonomian nasional, UMKM di Indonesia ternyata sulit berkembang. Faktor penyebab utama adalah keterbatasan akses pembiayaan dan pemasaran, serta tidak terintegrasinya rantai pasok ke sektor industri (Purba, 2019). Keterbatasan permodalan bagi pelaku UMKM adalah masalah yang juga dihadapi oleh para pelaku usaha UKM khususnya di Daerah Pasaman Barat. Kondisi cuaca ekstrim di perairan laut. Salah satunya yang terdampak adalah wilayah Kecamatan Sunga Beremas yaitu Kenagarian Air Bangis dikenal dengan sebutan daerah penghasil ikan terbesar di Kabupaten Pasaman Barat.

Untuk memulai kembali usaha dari nol memerlukan modal yang tidak sedikit. Bantuan bagi pelaku UKM berupa stimulan yang berasal dari Pemerintah maupun beberapa Organisasi lebih difokuskan pada penyediaan peralatan dan bahan baku diantaranya perahu, kulkas dan box penyimpanan ikan serta ikan mentah sebagai modal awal usaha. Keterbatasan modal yang diperoleh tersebut memerlukan pengelolaan yang tepat untuk memperoleh hasil maksimal. Alternatif lain yang dapat dipilih untuk pengembangan usaha mereka adalah memperoleh tambahan modal dalam bentuk uang dari lembaga permodalan dan perbankan.

Alternatif ini tentunya memiliki persyaratan-persyaratan administratif seperti proposal atau laporan transaksi keuangan yang pada umumnya belum dimiliki oleh pelaku UKM (Ferdiani, 2019). Beberapa kegiatan Pengabdian Kepada Masyarakat (PKM) terkait dengan Pembukuan Sederhana telah dilakukan. Seperti yang dilakukan oleh Ningrum et al. (2019) yang melakukan pengabdian pada ibu-ibu pengusaha catering. Hasil pelatihan pembukuan sederhana tersebut menumbuhkan kesadaran bagi UMKM tentang pentingnya pelaporan perpajakan pada suatu usaha melalui pembukuan sederhana. Selain itu melalui pembukuan dapat menciptakan pengelolaan manajemen yang baik sehingga berdampak pada peningkatan usaha catering. Selanjutnya pengabdian dengan judul Sosialisasi Penyusunan Laporan Keuangan Akuntansi Bagi Usaha Kelompok Industri Rumah Tangga Kecamatan Landasan Ulin Daerah Banjarbaru menunjukkan pemahaman peserta tentang teori akuntansi 


\section{PORTAL RISET DAN INOVASI PENGABDIAN MASYARAKAT (PRIMA) \\ VOLUME 1 ISSUE 2 (2022)}

dasar dan mereka mampu mengaplikasikan penyusunan laporan keuangan sederhana pada bisnis mereka (Candra et al., 2019). Pengabdian serupa juga dilakukan oleh Nabil et al. (2020) dimana hasilnya menunjukkan bahwa para pelaku usaha mendapat pengetahuan tentang bagaimana membuat pembukuan keuangan dalam menjalankan usaha mereka.

Kebutuhan laporan transaksi keuangan tentunya menjadi hal yang merepotkan bagi pelaku UKM ketika mereka tidak memiliki pengetahuan dan pemahaman tentang arti penting laporan transaksi tersebut. Melihat hal ini, maka kami dari pihak akademisi ingin berkontribusi bagi masyarakat di lingkungan sekitar dalam hal ini warga Kampung Padang Nagari Air Bangis dengan cara melakukan kegiatan pengabdian kepada masyarakat melalui kegiatan sosialisasi pembukuan sederhana bagi pelaku UKM Ikan Asin Perikanan Kampung Padang Nagari Air Bangis.

\section{METODE PENELITIAN}

Metode yang digunakan dalam pelaksanaan kegiatan PKM ini adalah melalui dua metode yakni sosialisasi peranan pembukuan sederhana bagi perkembangan UKM serta memberikan percontohan dalam perhitungan biaya produksi pada usaha ikan kering serta contoh perhitungan biaya produksi yang dikeluarkan selama satu kali proses produksi. Metode ini dilakukan dengan cara ceramah yang disertai dengan diskusi seputar permasalahan atau kendala yang dihadapi UKM mitra. Kegiatan ini dilaksanakan di daerah Kampung Padang, Kenagarian Air Bangis, Kec. Sungai Beremas, Kabupaten Pasaman Barat pada bulan Nopember 2019. Yang dilaksanakan di Aula Sekolah SDN 08 Sungai Beremas.

\section{HASIL DAN PEMBAHASAN}

Sebagaian wilayah Kecamatan Pasaman Barat Utara berbatasan langsung dengan laut dan merupakan daerah pesisir. Kondisi secara geografis yang terletak di daerah pesisir laut menyebabkan sebagian dari warga Air Bangis bergerak di bidang perikanan.

Berdasarkan hasil wawancara yang dilakukan dengan kepala jorong Kampung Padang Air Bangis terdapat 320 Kepala Keluarga dimana 90\% mata pencaharian utama warga mereka bergerak di bidang perikanan yang terbagi pada beberapa usaha yaitu sebagai pemilik bagan ikan, nelayan, pedagang ikan keliling, penjemur ikan kering serta pemilik usaha ikan asin. $10 \%$ sisanya adalah pekerja serabutan yaitu sebagai penggulung tali rafiah.

Salah satu Usaha Kecil Menengah yang bergerak di usaha ikan asin di Air Bangis adalah UKM Perikanan Kampung Padang yang beranggotakan 25 orang. Mereka telah memperoleh bantuan stimulan baik dari pemerintah maupun bantuan organisasi relawan dalam bentuk pemberian peralatan dan bahan baku. Keterbatasan modal untuk pengembangan usaha menjadi kendala bagi mereka ketika alternatif bantuan dana harus mereka dapatkan dari lembaga permodalan atau perbankan yang membutuhkan persyaratan adminitratif. Sehingga masalah utama yang dihadapi dalam usaha ikan asin UKM Perikanan Bangkit adalah:

1. Belum adanya pemahaman pentingnya pencatatan atas setiap usaha.

2. Belum memiliki pengetahuan tentang pembukuan sederhana bagi UKM.

Untuk mengatasi hal tersebut di atas, melalui kegiatan sosialisasi tim pengabdi menyampaikan beberapa materi pokok yakni pengertian dan manfaat pembukuan sederhana, elemen dalam laporan keuangan sederhana bagi UKM, elemen pembentuk biaya produksi. Pada tahap ini, salah satu materi yang dijelaskan oleh Tim Pengabdi adalah perlunya 
pemahaman pentingnya pemisahan Aset yang dimiliki usaha (Entitas) dengan harta milik pribadi di luar usaha.

Terkait dengan materi bentuk dan elemen laporan keuangan sederhana, Tim memberikan materi dalam bentuk pemaparan contoh tabel-tabel pencatatan transaksi serta cara pengisian tabel. Gambar 1 berikut ini adalah contoh perhitungan harga pokok produksi pada usaha ikan asin untuk satu kali proses produksi. Kartu ini juga berfungsi untuk memudahkan para pengusaha (produsen) dalam menentukan berapa biaya yang dikeluarkan setiap pengerjaan suatu pesanan atau proses produksi dilakukan.

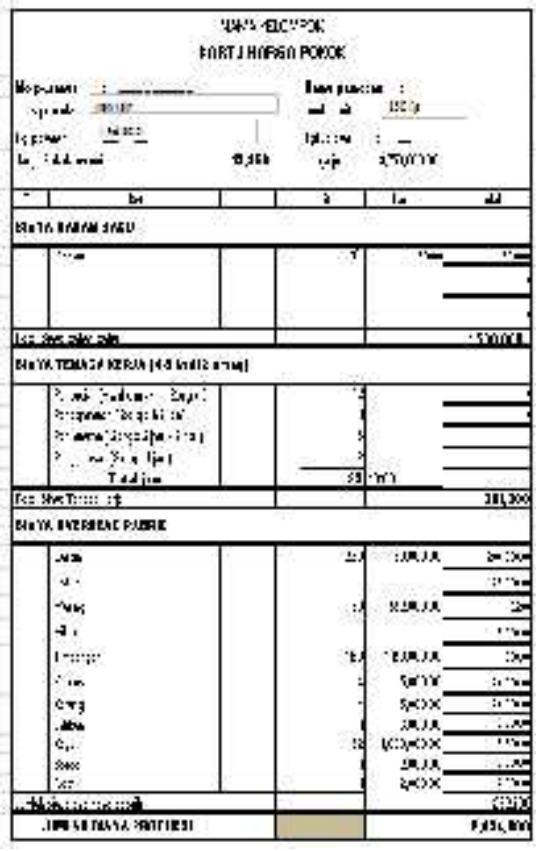

Gambar 1 Kartu Harga Pokok Produksi

Selain pemaparan contoh Kartu Harga Pokok Produksi, tim juga memaparkan contoh Buku Kas (Gambar 2) untuk melihat aliran Kas Masuk dan Aliran Kas Keluar yang terjadi pada kegiatan usaha mereka. Gambar 3 menunjukkan Buku Persediaanyang berfungsi untuk membantu mereka dalam melihat arus keluar masuk persediaan bahan baku.

\begin{tabular}{|c|c|c|c|c|}
\hline \multicolumn{5}{|c|}{ BUKU KAS } \\
\hline \multirow{3}{*}{$\begin{array}{r}\text { TARBGAL } \\
\text { IJ } \\
119 .\end{array}$} & UEAIAI & Renusukxt & PEUGELUARWA & EALDO \\
\hline & 22.0 & & & ISN-stove \\
\hline & Ewrital Chon $23<1$ & & $\sin$ & $9, \cdots, \cdots$ \\
\hline & 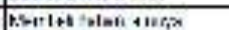 & & mints & $0,000,000$ \\
\hline$=n$ & hrome os cines:" & $1 \mathrm{~m} m \mathrm{~m}-$ & & $1,0,-\infty, \infty 0$ \\
\hline \multirow[t]{4}{*}{$5-14$} & 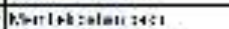 & & F!::5:2 & $., i=6,000$ \\
\hline & 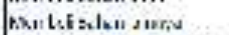 & & Lwovs. & $\therefore \therefore$ - \\
\hline & 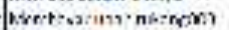 & & tomn & $1,7-60 \%$ \\
\hline & 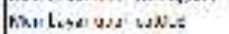 & & awove: & $\therefore$ Sosiceu \\
\hline $10 \mathrm{mo}$ & 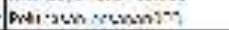 & تnamen & & $97,7, \mathrm{wo}$ \\
\hline \multirow{2}{*}{3.14} & 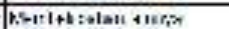 & & 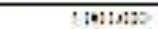 & $x, i 00,000$ \\
\hline & wrrites curturen & & Ge:Lm & 19,5 , su1 \\
\hline \multirow[t]{2}{*}{$\because: 14$} & 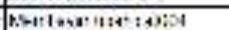 & & 1.4:5:20 & $10 \times 00,204$ \\
\hline & 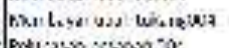 & $1 \times \infty 0_{0}$ & 2, wovs $=$ & a.s...... \\
\hline
\end{tabular}

Gambar 2 Buku Kas 


\section{PORTAL RISET DAN INOVASI PENGABDIAN MASYARAKAT (PRIMA) \\ VOLUME 1 ISSUE 2 (2022)}

Selanjutnya, dalam ilmu akuntansi kertas kerja sebagaimana yang dicontohkan pada Gambar 4 dikenal dengan istilah neraca lajur. Namun tim pengabdi membuat contoh kertas kerja yang lebih sederhana sehingga memudahkan mereka dalam menyusun laporan keuangan. Mengingat keterbatasan waktu sosialisasi serta kepadatan materi yang disampaikan tim pengabdi hanyamenyampaikan bahwa laporan keuangan pada umumnya terdiri dari Neraca yang menggambarkan posisi Aset/ harta, posisi Hutang dan Modal. Sementara Laporan Laba Rugi menggambarkan Laba yang diperoleh dari hasil pendapatan usaha (penjualan produk) dikurangi dengan biaya yang dikeluarkan yang dapat dilihat dari kartu harga pokok produk. Terakhir adalah Laporan perubahan modal yang mereka miliki sejak awal sampai dengan akhir periode laporan keuangan.

Selanjutnya pada tahap diskusi, tim menemukan fakta bahwa banyak dari peserta belum melakukan pencatatan transaksi usaha ikan asin mereka. Adapun pencatatan yang mereka lakukan sebatas kas yang masuk dan kas yang keluar. Ini menjadi alasan mendasar kesulitan permodalan yang dihadapi oleh para calon pelaku UKM maupun pelaku UKM. Masalah lain yang dihadapi pelaku usaha adalah tidak adanya pemisahan asset usaha. Ini berdampak pada perhitungan hasil usaha dalam hal posisi perubahan ekuitas (modal usaha). Selama ini, hasil usaha ikan asin yang mereka peroleh tidak menunjukkan hasil usaha yang sesungguhnya karena belum adanya pemisahan entitas usaha dengan kekayaan pribadi. Belum ada pencatatan yang terpisah antara harta pribadi yang ada sebelum melakukan usaha dan harta yang diperoleh dari usaha. Selain itu, hasil usaha dari ikan asin digunakan untuk pembiayaan kebutuhan rumah tangga tanpa proses pencatatan yang benar (dalam akuntansi, pengambilan pribadi disebut sebagai prive) padahal ini berdampak pada informasi keuangan tentang perubahan modal usaha di akhir periode.

Pembahasan materi penentuan elemen pembentuk harga pokok produksi, timbul beberapa pertanyaan tentang elemen-elemen yang diperhitungkan sebagai harga pokok produk pada usaha ikan asin mereka. Hal ini sangat menarik perhatian Tim, karena banyak dari mereka yang belum memasukkan beberapa elemen sebagai biaya produksi sehingga keuntungan yang mereka dapatkan selama ini belum menggambarkan keadaan yang sesungguhnya karena keuntungan yang mereka perhitungkan lebih tinggi dari yang seharusnya. Sebagai contoh mereka tidak memperhitungkan biaya jika terjadi kerusakan peralatan seperti perahu, alat jemur ikan, kulkas dan peralatan lainnya sehingga tidak ada alokasi biaya depresiasi untuk peralatan tersebut. Penentuan elemen-elemen pada laporan keuangan menjadi penting karena akan dijadikan dasar dalam penentuan harga jual dan perhitungan laba rugi usaha. Beberapa kendala yang dihadapi juga diungkapkan pada sesi diskusi dan tanya jawab. Seperti kendala yang dihadapi ketika jumlah persediaan ikan kering menumpuk sementara tingkat permintaan di pasar mengalami penurunan. Mereka membutuhkan freezer untuk penyimpanan ikan asin yang sudah siap dijual agar kualitas produk ikan asin tetap terjaga.

Kebutuhan peralatan ini mempengaruhi harga penjualan ikan asin terutama pada saat persediaan menumpuk. Hasil sosialisasi pada UKM Ikan Asin Perikanan Bangkit Mamboro Barat menunjukkan:

1. Peningkatan pengetahuan peran penting penyusunan Laporan Keuangan meskipun dalam bentuk pembukuan yang sederhana. 
2. Peningkatan pemahaman tentang bentuk pembukuan sederhana yang dapat mereka susun dan

3. Peningkatan pengetahuan tentang dasar penentuan perhitungan harga pokok produk.

Hasil pengabdian ini menunjukkan hasil yang serupa dengan pengabdian yang dilakukan oleh Ningrum et al. (2019) dan Candra et al. (2019) yang menunjukkan adanya peningkatan pengetahuan tentang pembukuan sederhana pada pelaku usaha dalam hal ini pelaku UKM. Namun pengabdian ini masih terbatas pada sosialisasi sehingga luaran yang kami harapkan adalah peningkatan pengetahuan dan pemahaman tentang pembukuan sederhana yang diperoleh melalui pemaparan contoh perhitungan pada usaha Ikan Asin yang mereka geluti. Ini menjadi tantangan bagi kalangan akademisi agar para pelaku UKM benarbenar dapat meningkatkan kesadaran mereka tentang arti penting laporan keuangan melalui pembukuan dalam pengembangan usaha mereka selanjutnya.

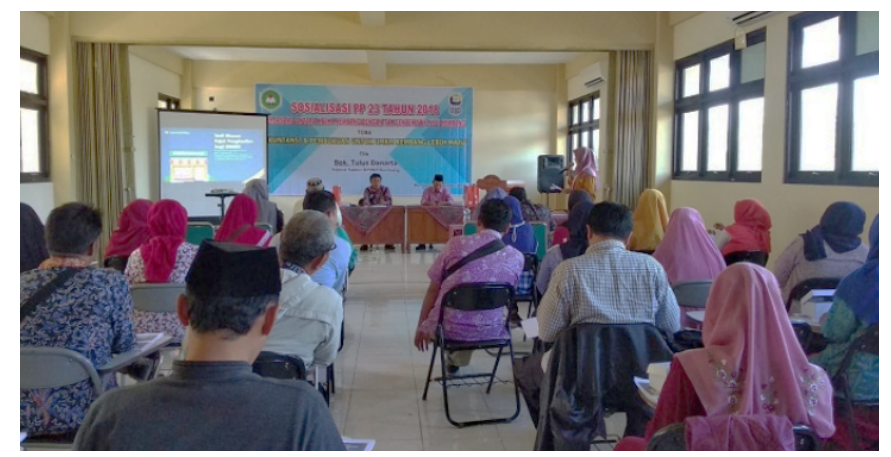

Gambar 3 Pelaksanaan Kegiatan

\section{KESIMPULAN}

Berdasarkan hasil kegiatan pengabdian dalam bentuk Sosialisasi Pembukuan Sederhana pada UKM Ikan Asin Perikanan Kampung Padang Air Bangis Daerah Pasaman Barat menunjukkan peningkatan pengetahuan dan pemahaman tentang manfaat pembukuan sederhana serta bentuk-bentuk laporan keuangan. Mereka mulai memahami Konsep Entitas Bisnis serta mengetahui beberapa bentuk pembukuan sederhana dan komponen pembentuk harga pokokproduk usaha ikan asin mereka. Potensi geografis yang sangat mendukung perkembangan usaha UMKM di Daerah Pasaman Barat khususnya bidang perikanan harus didukung oleh ketersediaan sarana dan prasarana yang maksimal seperti pendanaan (modal) agar tujuan UMKM untuk menciptakan kemandirian secara ekonomi dapat tercapai. Peran akademisi bidang keilmuan Akuntansi masih sangat dibutuhkan dalam bentuk pemberian pelatihan pembukuan secara berkelanjutan bagi pelaku UMKM di Daerah Pasaman Barat. Pembukuan adalah hal yang merepotkan bagi beberapa pelaku UKM, sehingga dibutuhkan trik dalam pelatihan yang memudahkan pelaku UKM untuk berupaya membuat laporan usaha, yang dilakukan dengan pencatatan manual ataupun pemanfaatan aplikasi pelaporan keuangan dengan menggunakan android. 


\section{DAFTAR PUSTAKA}

Candra, H. K., Iryanie, E., Heldalina, H., \& Wulandari, P. A. (2019). Sosialisasi Penyusunan Laporan Keuangan Akuntansi Bagi Usaha Kelompok Industri Rumah Tangga Kecamatan Landasan Ulin Kota Banjarbaru. Jurnal Impact: Implementation and Action, 1(1), 74-80.

Ferdiani, K. R. (2019). Syarat dan Ketentuan Mengajukan Pinjaman Modal untuk UMKM. Www.Modalrakyat.Id. https://www.modalrakyat.id/blog/syarat-dan-ketentuanmengajukanpinjaman-modal-untuk-umkm

Nabil, M., Ma'ruf, R., Arifah, T., \& Wulansari, A. (2020). Pelatihan Pengembangan Pengelolaan Dan Pemasaran Bagi Pelaku-Pelaku Umkm Ceriping Di Desa Mandisari. ABDIPRAJA (Jurnal Pengabdian Kepada Masyarakat), 1(1), 66-71.

Ningrum, E. P., Yoganingsih, T., Ratriningtyas, N., Winarso, W., \& Setyawati, N. W. (2019). Pelatihan Pembukuan Sederhana, Sosialisasi Perpajakan dan Pengelolaan Manajemen Bagi UMKM Ibu-Ibu Catering Perumahan Jatimulya RW. 012. Jurnal ABDIMAS (Pengabdian Kepada Masyarakat) UBJ, 2(2).

Purba, G. N. (2019). Peran UMKM Bagi perekonomian Nasional. Www.Medcom.Id. https://www.medcom.id/ekonomi/mikro/4ba5Vdrbperan-umkm-bagi-perekonomiannasional

Ridwan, M., \& Tarmizi, M. H. (2020). Sistem Sosialisasi Informasi Pemerintahan Desa Dan UKM (Usaha Kecil Menengah) Desa Berbasis Website Dengan Menggunakan Pendekatan Content Management System (CMS) Studi Kasus: Desa Wonosekar Kecamatan Gembong, Pati.

Yolandha, F. (2020). Palu Sebut 60 Persen Omzet UMKM Anjlok Akibat Covid-19. REPUBLIKA.CO.ID,. https://www.republika.co.id/berita/qcn6ao370/palu-sebut-60persen-omzet-umkm-anjlok-akibat-covid19 